\title{
IMMUNOHISTOCHEMICAL DISTRIBUTION OF SOME REGULATORY PEPTIDES IN THE RAT STOMACH
}

\author{
Mohamed Elnasharty ${ }^{a}$ and Mohamed Alkafafy ${ }^{b}$ \\ a Department of Histology and Cytology, Faculty of Veterinary Medicine, Alexandria \\ University (Damanhur Branch), Albostan, Behera, Egypt \\ ${ }^{b}$ Department of Cytology and Histology, Faculty of Veterinary Medicine, Minufiya \\ University, Sadat City Branch, Egypt
}

\begin{abstract}
The innervation of the rat stomach has been re-analyzed using immunohistochemical localization of cholinergic markers. These include the common type of choline acetyltransferase (cChAT) and the peripheral type ( $p C h A T)$, which is the product of a splice variant of ChAT $m R N A$ and preferentially localized to peripheral cholinergic nerves. In addition we studied the immunolocalization of vesicular acetylcholine transporter (VAChT), neuronal nitric oxide synthase (nNOS) and tyrosine hydroxylase (TH). Paraffin embedded tangential sections from the rat stomach were used to demonstrate the immunolocalization of cholinergic and nitrergic neurons and nerve fibers in the rat stomach using antibodies to $p C h A T, c C h A T, V A C h T$ and nNOS. A ganglionated submucosal plexus (SP) was almost absent from the gastric wall, apart from some scattered neurons. Most myenteric plexuses (MP) in the rat stomach showed positive immunostaining for pChAT, cChAT and nNOS only, whereas VAChTand TH-immunoreactivities (IR) were observed in the form of varicose nerve fibers and nerve terminals in the rat gastric wall. These results indicate that in the rat gastric wall, submucosal and myenteric nerve fibers showed heterogeneous staining with regard to the examined
\end{abstract}


regulatory peptides and transmitters. The submucosal neurons were almost absent, while the myenteric neurons showed only $p C h A T$, cChAT and nNOS immunostaining suggesting morphological evidence for the roles of cholinergic, nitrergic and adrenergic mechanisms in stomach secretory and motor functions.

Keywords: Immunohistochemistry; Choline acetyltransferase; Acetylcholine transporter; Neuronal nitric oxide synthase; Tyrosine hydroxylase; Stomach; Rat.

\section{INTRODUCTION}

The stomach, because of its location in the upper part of the alimentary canal, is exposed to many harmful substances of exogenous origin such as toxins, alcohol and drugs. The major gastric functions are under the control of the enteric nervous system (ENS). The neuronal circuits involved in this control are poorly understood in rats. Although, the neurochemical coding and projection patterns of enteric neurons have been fairly well investigated in the guinea pig stomach (Schicho et al., 2001; Pimont et al., 2003), relatively little is known about these in the rat stomach. Cholinergic neurons have been demonstrated in the ENS by functional and biochemical methods, but not by antibodies that provide information on the localization of the synthesizing enzymes (Chiocchetti et al., 2003). Although a small ganglionic submucosal plexus exists in larger animals and humans, the vast majority of enteric neurons are still located in the myenteric plexus and consequently the neurons of the MP might be involved in control of gastric motor functions as well as mucosal functions (Keast et al., 1985; Pimont et al., 2003; Rauch et al., 2006).

$\overline{\text { Kafrelsheikh Vet. Med. J. Vol. } 8 \text { No. } 1 \text { (2010) }}$ 
Many of the neurotransmitters found in the central nervous system (CNS) have also been identified in the ENS of many species, including humans (for reviews see:Furness and Costa,1982; Taylor and Bywater, 1989; Dockray, 1994; Reiche et al., 2001; Pimont et al., 2003).

ChAT immunoreactivity (ChAT-IR) has been successfully used to visualize cholinergic neurons and their processes in the CNS, but less successfully applied to the peripheral cholinergic system (Reiche and Schemann, 1999; Hoover et al., 2004). A splice variant of ChAT mRNA, which lacks exons 6-9 in the DNA coding region, has been cloned from rat pterygopalatine ganglion (Tooyama and Kimura, 2000). Because of its predominant localization in peripheral neurons, the protein product of the mRNA variant was designated ChAT of a peripheral type (pChAT). The conventional ChAT protein, found in both central and peripheral neurons, was called ChAT of the common type (cChAT). Although the antibody against pChAT is capable of detecting some positive neurons in the CNS (Kanayama et al., 2003; Yasuhara et al., 2003), pChAT has proved to be a powerful marker for peripheral cholinergic structures (Nakajima et al., 2000; Chiocchetti et al., 2003; Yasuhara et al., 2007). In addition it is worth noting that antibody against VAChT more clearly identifies central and peripheral cholinergic nerve fibers and terminals than does ChAT-IR, which tends to be concentrated in perikarya (Weihe et al., 1996; Li and Furness, 1998).

Tyrosine hydroxylase, the enzyme responsible for synthesis of DOPA and rate-limiting for subsequent production of catecholamines, is located at sites in the digestive tract other than sympathetic nerve endings. The existence of enteric dopaminergic neurons has also been observed in the ENS of mice and sheep (Li et al., 2004; Mazzuoli et al., 
2008). nNOS is the enzyme that catalyses the synthesis of nitric oxide (NO), which is a cell-derived highly diffusible and unstable gas involved in intercellular and intracellular communication in the nervous system as well as an inhibitory transmitter of motor neurons in the gut (Arnhold et al., 2004). As an inhibitory transmitter of non-adrenergic, noncholinergic neurons, nitric oxide is involved in muscle relaxation, vasodilatation, acid secretion, and mucus secretion (Brookes, 1993; Nakamura et al., 1998) and so nNOS plays an important role in the relaxation of smooth muscles.

The aim of this study was to identify and summarize some features of neural components within the ENS of the rat stomach. We compared the distribution patterns and staining features of pChAT and cChAT in gastric MP neurons to determine the correspondence between them and whether pChAT is a marker of neurons that have been previously been identified as cholinergic, but which are weakly immunoreactive for cChAT. VAChT-immunoreactive (IR) neurons, nitrergic systems (by establishing the presence of nNOS-IR) and dopamine (by establishing the presence of TH-IR) in the rat stomach, were also examined.

\section{MATERIALS AND METHODS}

Procedures involving animals and their care were conducted in conformity with the standards for animal experiments in our university and are in compliance with the National Institutes of Health (NIH) Guide for the Care and Use of Laboratory Animals (1996).

A total of 15 male Wistar rats, weighing 250-350 g were used in this study. Under pentobarbital anesthesia (50-80 $\mathrm{mg} / \mathrm{kg}$, i. p.), each animal was killed and the stomach removed and fixed by immersion in 
neutral-buffered formalin for at least 2 days. The material was then dehydrated, cleared and embedded in paraffin wax. 5-8 $\mu \mathrm{m}$ thick sections were cut in tangential and transverse planes in relation to the outer surface of the stomach, and mounted on gelatin-coated glass slides.

Immunostaining was performed using the avidin-biotin complex (ABC) technique. Specificity, working dilution, and sources of the primary antibodies used are summarized in Table 1. After dewaxing and rehydration the paraffin sections of the stomach were treated for 30 minutes with $0.3 \%$ hydrogen peroxide in methanol at room temperature to eliminate endogenous peroxidase activity and then incubated with a primary antibody. The biotinylated secondary antibodies of an appropriate species (diluted 1:2,000; Vector Laboratories, Burlingame, CA, USA) were then applied for $1 \mathrm{~h}$ at room temperature. Later on avidin-biotinylated peroxidase complex (diluted 1:2,000; ABC Elite, Vector Laboratories) was used for $1 \mathrm{~h}$ at room temperature. With antibodies to pChAT, cChAT and VAChT, sections were incubated for 3-4 days at $4{ }^{\circ} \mathrm{C}$, while with antibodies to PGP 9.5, TH and nNOS sections were reacted overnight at room temperature. Dilution of the reagents and washing sections between each step were done with phosphate buffered saline (PBS). Color was developed by treating the sections for $10 \mathrm{~min}$ with a mixture containing $0.02 \% \quad 3,3^{\prime}$ diaminobenzidine (DAB), $0.0045 \% \mathrm{H}_{2} \mathrm{O}_{2}$ and $0.3 \%$ nickel ammonium sulfate in $50 \mathrm{mM}$ Tris- $\mathrm{HCl}$ buffer $(\mathrm{pH} \mathrm{7.6)}$. The stained sections were dehydrated by alcohol, cleared in xylene, and mounted in Entellan (Merck; Darmstadt, Germany). For immunohistochemical controls, either primary, secondary antiserum or the $\mathrm{ABC}$ reagent was omitted. No positive staining was observed in these controls. 


\section{RESULTS}

\section{pGP 9.5:}

The results of the current study showed that there was a great variety in staining affinity and distribution patterns of the neuronal markers used for the various neurotransmitters. PGP, 9.5 immunostaining gave a strong positive reaction in the gastric wall as a whole with staining in the MP, in the nerve fibers supplying the muscular coat, in the submucosal nerve fibers and in some submucosal neurons (Fig. 1A, B, D). Staining with PGP, 9.5 showed that there was an almost complete absence of ganglia in the submucosa of the stomach apart from some rare submucosal neurons (Fig. 1C).

\section{cChAT:}

The common type of choline acetyltransferase (cChAT) showed positive reactivity in the MP (Figs. 2A, B), in nerve fibers supplying the muscular coat of the gastric wall (Fig. 2C), and in the nerve fibers of the submucosa (Fig. 2D). Nuclei of the cChAT-IR myenteric neurons were usually unstained.

\section{pChAT:}

The peripheral type of choline acetyltransferase (pChAT) gave a strong positive reaction in the myenteric plexuses and the submucosal nerve fibers. High proportions of nerve cell bodies in the myenteric plexuses of the rat stomach were immunoreactive for pChAT. The MP consisted of large ganglia interconnected by thick nerve bundles. These ganglia were densely packed with nerve cell bodies (perikarya), from which projections could be seen passing both up and down the plane of 
the plexus and perpendicularly to the mucosa and through both muscle layers (Figs. 3A, B). The pChAT-immunoreactivity was mainly cytoplasmic with variable nuclear staining. The intensity of pChAT labeling varied considerably between neurons and did not appear to be homogeneous throughout the cytoplasm, with condensed immunoreactivity being located eccentrically in the perikarya and in particular close to the emergence of the axon. In the MP, the strongly pChAT-IR neurons, which were generally large and oval in shape, were easily identified (Fig. $3 C)$. Relatively weak reactivity of pChAT was noticed in the nerve bundles supplying the muscular coat. In the submucosa, the positive pChAT nerves were mostly arranged around the blood vessels supplying the gastric wall and extended in between the gastric glands (as previously observed by Nakajima et al. (2000) (Fig. 3D).

\section{VAChT:}

The staining affinity and distribution pattern of VAChT was somewhat different from that of both cChAT and pChAT. The myenteric neurons and nerve fibers, as well as submucosal nerve fibers, showed only positive reactivity for $\mathrm{VAChT}$ in the form of puncta or varicose terminals around the neuronal cell bodies (Figs. 4A, B). Similar varicose fibers were noticed running in between the muscles of the gastric wall (Fig. 4C).

\section{nNOS:}

The nNOS staining and distribution pattern was localized mainly in the MP and in the nerve fibers of the smooth muscles of the tunica muscularis. Some of the nNOS positive fibers reached a level just below the gastric glands in the mucosa. The nNOS positive myenteric neurons 
appeared polyhedral in shape with long cytoplasmic processes emerging in various directions (Fig. 5A). The extensive number of nNOS positive nerve fibers supplying the smooth muscle layer of the rat stomach showed a varicose regular appearance (Fig. 5B).

\section{TH:}

The staining affinity of $\mathrm{TH}$ was localized only in the submucosal nerve fibers without any positive reaction in the myenteric plexuses (Fig. 5C). The TH positive nerve fibers were also of a varicose type (Fig. 5D). In almost all preparations, there was a complete absence of TH-IR perikarya in the MP.

\section{DISCUSSION}

The ENS is larger and more complex than other regions of the PNS, reflecting its ability to regulate enteric behavior in the absence of CNS input (Gershon et al., 1994; Furness et al., 2000; Reiche et al., 2001; Li et al., 2004). Spatially, the intestinal ENS is divided into the myenteric and submucosal plexuses (Lee and Nam, 2006). The stomach, however as documented in the current study, lacks a well-developed ganglionated submucosal plexus and the perikarya of enteric neurons innervating the muscle or the mucosa appear to be localized within the MP (Pfannkuche et al., 1998b; Schemann et al., 2001). Since the stomach lacks a ganglionated submucosal plexus, the neurochemical code of submucosal neurons determined in the other regions of the gut, is found expectedly in some gastric myenteric neurons, i.e. in the stomach, a submucosal plexus may simply be fused and incorporated into the MP.

The enteric plexuses contain intrinsic primary afferent neurons (IPANs) and interneurons that enable the ENS, independent of the CNS, to mediate integrative responses to local stimuli. The physiological

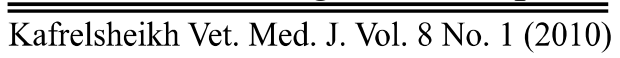


functions of the ENS include the control of gastrointestinal motility, circulation, secretion, and mucosal transport (Schemann et al., 2001; Li et al., 2004). In support of previous reports, our results show that the gastric circular and longitudinal muscle layers are innervated by cholinergic, adrenergic and nitrergic neurons located in the MP (Michel et al., 2000; Schicho et al., 2001). These gastric enteric plexuses, which innervate smooth muscle or mucosal layers and play important roles in regulating gastric secretion and motility (Furness et al., 1991; Pfannkuche et al., 1998a), receive a dense and intricate network of vagal cholinergic efferent axons (Berthoud, 1995; Holst et al., 1997; Zheng and Berthoud, 2000; Yuan and Yang, 2002) as confirmed by pharmacological experiments performed on isolated rat stomach (Welsh et al., 1994). It is widely accepted that the vagus nerve is cholinergic in nature innervating the abdominal viscera, including the stomach (Ruggiero et al., 1993; Ferreira et al., 2001). However, our study has been the first to compare the distribution pattern of both types of ChAT enzymes and VAChT as well as those of the pan-neural marker, PGP 9.5, and $\mathrm{TH}$ in the rat gastric wall. Although some differences do exist, the distribution patterns of myenteric nerve cell bodies and nerve fibers immunoreactive to the markers used in this study in the stomach of the rat are broadly similar to that described in other mammalian species. Our study shows that the vast majority of enteric neurons are located in the MP in contrast to other gut regions, which parallels observations of Keast et al. (1985). Our findings were also confirmed by the results obtained from PGP 9.5 immunostaining. PGP 9.5 is a well established general marker for the majority of peripheral autonomic neurons, including enteric ones, and has been widely used in descriptive studies (Johnson et al., 1998; Toole et al., 1998). 
Since ChAT is accepted to be the most reliable marker for cholinergic structures and it has been recognized that most ChAT antibodies fail to identify cholinergic nerves in peripheral tissues (Arvidsson et al., 1997; Hoover et al., 2004; Yasuhara et al., 2007) we used the pChAT and VAChT antibodies to re-evaluate them in the gastric wall of rat. Immunoreactivity to the cholinergic marker of both types of ChAT in neural elements innervating smooth muscle, submucosal blood vessels and mucosa of rat stomach were largely similar indicating that $\mathrm{pChAT}$ can be a reliable alternative cholinergic marker for those neurons and nerve fibers showed cChAT immunoreactivity.

pChAT immunoreactivity was detected in the majority of neurons in the gastric MP, in scattered submucosal neurons, in nerve fibers innervating the blood vessels and in gastric glands. In agreement with these findings, an abundant expression of pChAT-IR in the ileum (in rat, pig and guinea pig) and in the stomach and duodenum (in guinea pig) has been described (Brehmer et al., 2004; Nakajima et al., 2000; Chiocchetti et al., 2003; Yuan et al., 2005). Previous studies have indicated that the IPANs have weak immunoreactivity for cChAT ( $\boldsymbol{L i}$ and Furness 1998; Chiocchetti et al., 2003) whereas IPANs were strongly immunoreactive for pChAT in the current study. This implies that pChAT is a major enzyme for ACh synthesis in these neurons (Chiocchetti et al., 2003). The pChAT-IR varicose fibers were seldom seen in the interganglionic connectives, in the ganglia or in the mucosa in the current study. In parallel, Chiocchetti et al. (2003) identified prominent non-varicose pChAT fibers in the guinea pig ileum.

The cChAT immunoreactivity was mainly cytoplasmic and no nuclear staining was observed in our study. Similar results were reported in the guinea pig MP of the small intestine (Li and Furness, 1998; Neunlist et al., 2001; Chiocchetti et al., 2003; Xu et al., 2005), and in Kafrelsheikh Vet. Med. J. Vol. 8 No. 1 (2010) 
rat ileum (Mann et al., 1999; Harrington et al., 2007). Most myenteric neurons of guinea pig stomach contain ChAT or NOS (Schemann et al., 1995; Vanden Berghe et al., 1999; Iino, 2000). In further agreement cholinergic neurons have been described in the myenteric, but not the submucosal plexus of the rat stomach, and were immunoreactive for cChAT (Furness et al., 2000). Moreover ChAT-IR nerve fibers were observed in thick-walled blood vessels in the submucosa, and in some cases, at the inner lining of the blood vessel as well as in neurons within the myenteric plexus. They were also observed in the circular muscle and in the neurons situated in ganglia subjacent to the gastric epithelium (Adami et al., 2002). On the contrary, Yuan et al., (2001) observed dense ChAT-IR fibers surrounding the gastric ganglionic cells without ChAT immunoreactivity in the cytoplasm. The ChAT-IR fibers may represent vagal preganglionic fibers, which are of central origin and, together with the ChAT-IR myenteric neurons, are involved in excitatory pathways, i.e., secretomotor neurons, though some are thought to be IPANs supplying the mucosal epithelium (Pfannkuche et al., 1998a, 2000; Sang and Young, 1996; Mann et al. 1999; Yuan et al., 2001, 2002; Harrington et al., 2005; Wang et al., 2005; Dun et al., 2006).

We demonstrated that the MP was also immunoreactive for the vesicular acetylcholine transporter (VAChT). In accordance with our results, VAChT-IR was described in nerve fibers of the MP, circular muscle, submucosal arterioles and the deep muscular plexus of rat ileum (Harrington et al., 2007), but not in the perikarya (Li and Furness, 1998; Li et al., 1998). The presence of VAChT in varicosities in all terminal fields of the IPANs implies that all such terminals release acetylcholine. This has particular implications for the mucosal terminals. Acetylcholine is a stimulant of the mucosal epithelial cells and promotes water and electrolyte secretion (Li and Furness, 1998). 
In the present study, the nNOS-IR was localized mainly in the MP and in the nerve fibers within the tunica muscularis, including those reaching the level of the gastric glands in the mucosa. This agrees with studies showing fibers expressing nNOS that were present predominantly in the external muscle layer and the muscularis mucosae of the stomach wall (Toole et al., 1998; Young et al., 2002; Schicho et al., 2004). In rats, the axonal projections of nNOS-IR gastric myenteric neurons provide an extensive network of fibers running within the circular smooth muscle layer in a higher proportion than cholinergic ones (Berthoud, 1995; Jarvinen et al., 1999; Schemann et al., 2001). In addition, in the guinea pig, the gastric circular and longitudinal muscle layers receive ascending excitatory cholinergic innervation and descending inhibitory nitrergic innervation (Schemann and Schaaf, 1995; Michel et al., 2000; Schemann et al., 2001; Arnhold et al., 2004; Wang et al., 2005; Sarna, 2007; Harrington et al., 2007), whereas in the small intestine two types of neurons express NOS: motor neurons to the muscle and descending interneurons (Chiocchetti et al., 2003). Consistent with this, nNOS-IR neurons being inhibitory motor neurons, supply numerous terminals in the circular muscle of the rat small intestine (Aimi et al., 1993), but relatively few in the myenteric ganglia and are not observed in the perivascular plexuses and are very rare in the mucosa of mouse intestine (Sang and Young,1996; Arnhold et al., 2004) and human gastric antrum and jejunum (Miller et al., 2001). The activation of gastric myenteric neurons is mediated by vagal nicotinic pathways and includes cholinergic and NOS synthesizing neurons, suggesting a central regulation of both excitatory and inhibitory myenteric pathways during acute cold exposure and may form an integral part of the neural alarm and protection system in the stomach as a protective mechanism against acid induced injury of the mucosa (Yuan $\overline{\text { Kafrelsheikh Vet. Med. J. Vol. } 8 \text { No. } 1 \text { (2010) }}$ 
et al., 2001). In the ENS, nitric oxide (NO) is regarded as an important messenger for the non-adrenergic and non-cholinergic neurotransmission and synthesized mainly by the NOS (Arnhold et al., 2004). NOS-IR neurons project selectively to the gastric fundus and may be involved in vagal reflexes controlling gastric distension (Guo et al., 2001; Brehmer et al., 2004).

The current study has documented that the staining affinity of $\mathrm{TH}$ is localized only in the submucosal varicose nerve fibers without any positive reaction in the myenteric plexuses. In partial agreement with the present findings, Dawirs et al. (1992) (in the gerbil), Toole et al. (1998) (in golden hamster) and $\mathbf{L i}$ et al. (2004) (in mouse and guinea pig stomach and intestine) found TH-IR varicose axons forming a dense network in the enteric plexuses with a few number of TH-IR neurons in the myenteric and submucosal plexus. In addition, rare varicose and nonvaricose TH-IR nerve fibers were also described projecting without branching through ganglia and interganglionic connectives of the myenteric and submucosal plexuses of guinea pig intestine (Browning et al., 1999; Wang et al., 2005; Iino, 2000). Despite this, Rauch et al. (2006) described a constant presence of TH-IR in myenteric ganglionic cells of human gut when comparing pre- and post-natal samples. Arterioles of all digestive tract regions had greater densities of TH-IR innervation than VAChT-IR innervation (Li et al., 1998). Dopamine (DA), synthesized by TH, in the gastrointestinal tract stimulates exocrine secretions, inhibits gut motility, modulates sodium absorption and mucosal blood flow (Kurosawa et 1991; Flemström et al., 1993; Finkel et al.,1994;Haskel et al., 1994), and is protective against gastroduodenal ulcer disease (Mezey and Palkovits 1992; Glavin and Hall, 1995; Mezey et al., 1996). The discrete population of TH-IR neurons projecting to the body of the stomach may comprise the preganglionic motor neurons $\overline{\text { Kafrelsheikh Vet. Med. J. Vol. } 8 \text { No. } 1 \text { (2010) }}$ 
involved in gastric relaxation obtained via withdrawal of cholinergic tone or could constitute a subpopulation of dopaminergic neurons involved in the attenuation of stress or chemically induced ulcers (Guo et al., 2001). Additionally, studies performed on MP neurons of the sheep abomasal descending neurons controlling the pyloric sphincter showed that they were predominantly NOS-IR, moderately ChAT and very little TH-IR (Mazzuoli et al., 2008).

It may be concluded that the functions of gastric muscles and mucosa are under the control of the ENS, which contains distinct populations of neurochemical peptides responsible for motor and secretory activity. One of the intriguing findings was that, unlike in the guinea-pig ileum, the longitudinal muscle of the stomach received a polarized innervation consisting of ascending excitatory and descending inhibitory neurons. The most likely explanation for this innervation pattern might be related to the specialized function of the stomach as a storage organ. In the stomach it has been shown that both muscle layers contract and relax at a given locus at the same time (Sarna, 1993). This synchronous motor activity has to be crucial for a hollow organ like the stomach (Schemann et al., 2001). Further investigations need to be undertaken to establish the origin, contribution and significance of pChAT in the ENS of the stomach.

\section{ACKNOWLEDGMENTS}

Dr. M. EInasharty was a visiting academic at the MNRC in Shiga University of Medical Science, Otsu, Japan in 2007. All thanks are forwarded to Professor H. Kimura, MNRC, Shiga University of Medical Science, Otsu; Shiga, Japan for his kind help and sincere advice. 
Immunohistochemical Distribution Of Some ...

Table (1)): Primary antibodies used.

\begin{tabular}{|c|c|c|c|c|c|}
\hline Primary Antibodies & Species & Type & Clone/serum & Source & Dilution \\
\hline Protein gene product, 9.5 (PGP 9.5) & Mouse & Monoclonal & $13 \mathrm{C} 4$ & UltraClone, UK & 1: 2000 \\
\hline $\begin{array}{l}\text { Choline acetyltransferase of } \\
\text { peripheral type (pChAT) }\end{array}$ & Rabbit & Polyclonal & & $\begin{array}{l}\text { Kind gift of } \mathrm{H} . \\
\text { Kimura }\end{array}$ & $1: 50,000$ \\
\hline $\begin{array}{c}\text { Choline acetyltransferase of common } \\
\text { type (cChAT AB144p) }\end{array}$ & Goat & Polyclonal & $\mathrm{AB} 144 \mathrm{P}$ & Chemicon, USA & $1: 500$ \\
\hline $\begin{array}{l}\text { Vesicular acetylcholine transporter } \\
\qquad(\mathrm{VAChT})\end{array}$ & Goat & Polyclonal & $\mathrm{AB} 1578$ & Chemicon, USA & $1: 10,000$ \\
\hline Nitric oxide synthase (nNOS) & Mouse & Monoclonal & NOS1 (A11) & $\begin{array}{c}\text { Santa Cruz } \\
\text { Biotechnology, CA }\end{array}$ & $1: 2000$ \\
\hline Tyrosine hydroxylase (TH) & Mouse & Monoclonal & MAB318 & Chemicon, USA & $1: 2000$ \\
\hline
\end{tabular}

\section{LEGENDS TO FIGURES}

Figure (1): Light micrograph of PGP 9.5 immunoreactivity in the rat stomach. The PGP, 9.5 immunostaining was positive in the myenteric plexus (arrows in A), large thick bundles (thick arrows in C and D) and thin bundles supplying the muscular coat of the rat stomach (thin arrows in A and D). A few scattered submucosal neurons were noticed in the submucosa of the rat gastric wall (thin arrow in C). In the rat intestinal wall (in B) there was a distinct submucosal plexus as well as myenteric plexus with positive PGP, 9.5 nerve fibers in the muscular coat (arrows in B). Mc, mucosa; $\mathrm{Sb}$, submucosa; Ms, Muscular tunic; MP, myenteric plexus.

Figure (2): Light micrograph of cChAT immunoreactivity showed positive neurons of myenteric plexus (MP), nerve fibers supplying the muscular coat of gastric wall and in the nerve fibers of the submucosa (arrows in D). Mc, mucosa; Sb, submucosa; Ms, Muscular tunic; MP, myenteric plexus.

$\overline{\text { Kafrelsheikh Vet. Med. J. Vol. } 8 \text { No. } 1 \text { (2010) }}$ 
Figure (3): Light micrograph of the pChAT immunoreactivity showed a strong positive reaction in the myenteric ganglionic plexus (MP) and nerve fibers (arrows in B). In the myenteric plexus, pChAT-IR neurons were large and oval in shape with either negative nuclei (thick arrows in C) or positive nuclei (thin arrow in C). pChATIR nerves ran around the blood vessels ( $\mathrm{Bv}$ in $\mathrm{D}$ ) supplying the gastric wall and extended in between the gastric glands (D). Mc, mucosa; Sb, submucosa; Ms, Muscular tunic.

Figure (4): Light micrograph of VAChT-IR in myenteric ganglionic plexus (MP), nerve fibers of blood vessels (BV), and in the nerve fibers of the muscular coat. Positive VAChT reaction was in the form of varicose terminals around the myenteric neuronal cell bodies (MG in B) and punctate or varicose fibers in the muscular coat (arrows in C). Sb, submucosa; Ms, muscular tunic.

Figure (5): Light micrograph of $\mathrm{nNOS}$ ( $\mathrm{A}$ and $\mathrm{B}$ ) and $\mathrm{TH}(\mathrm{C}$ and $\mathrm{D})$ immunoreactivity. nNOS-IR neurons of myenteric plexus (MP in A) were polyhedral in shape with long cytoplasmic processes emerging from them and running in between them. The nerve fibers of the Tunica muscularis were of a varicose type (B). TH immunoreactivity was localized only in the submucosal nerve fibers in varicose type fibers (arrows in C and D). Mc, mucosa; $\mathrm{Sb}$; submucosa; Ms, muscular tunic. 
Immunohistochemical Distribution Of Some ...

Fig. (1):

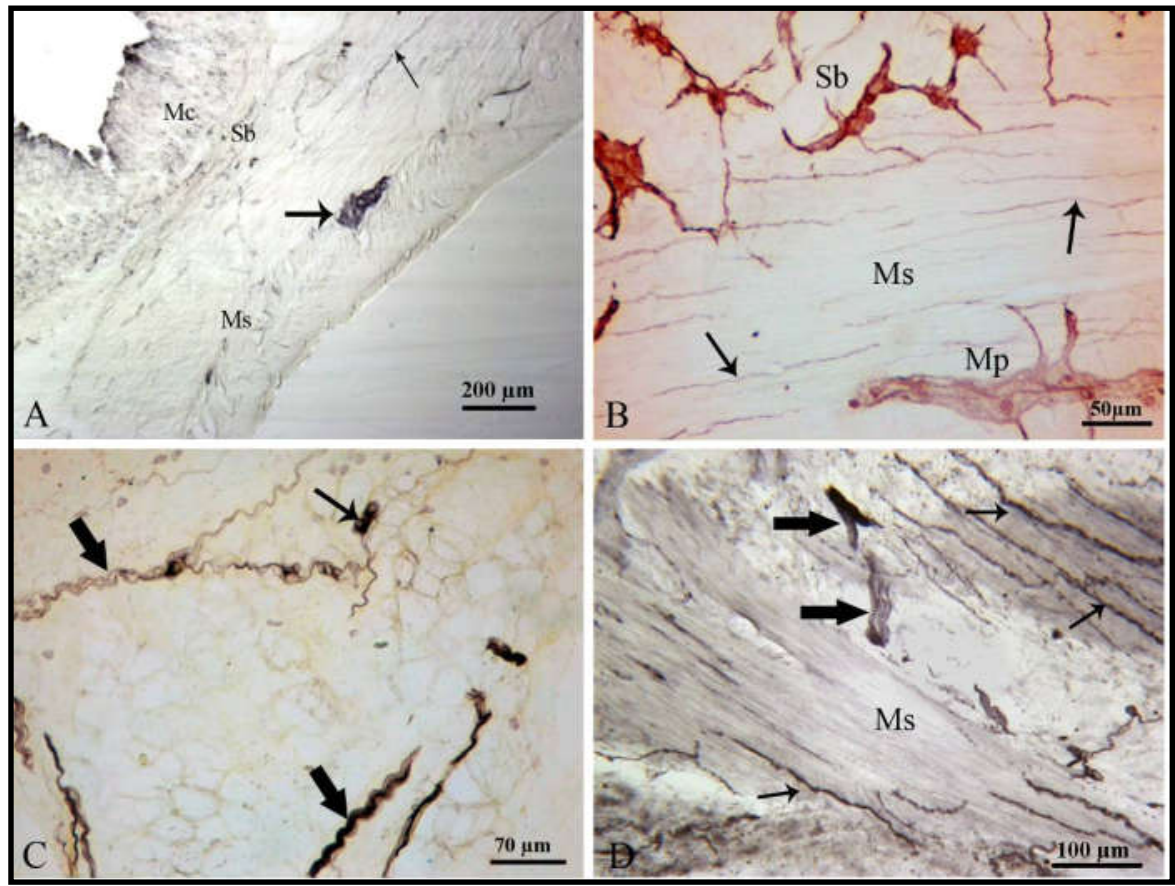

Fig. (2):

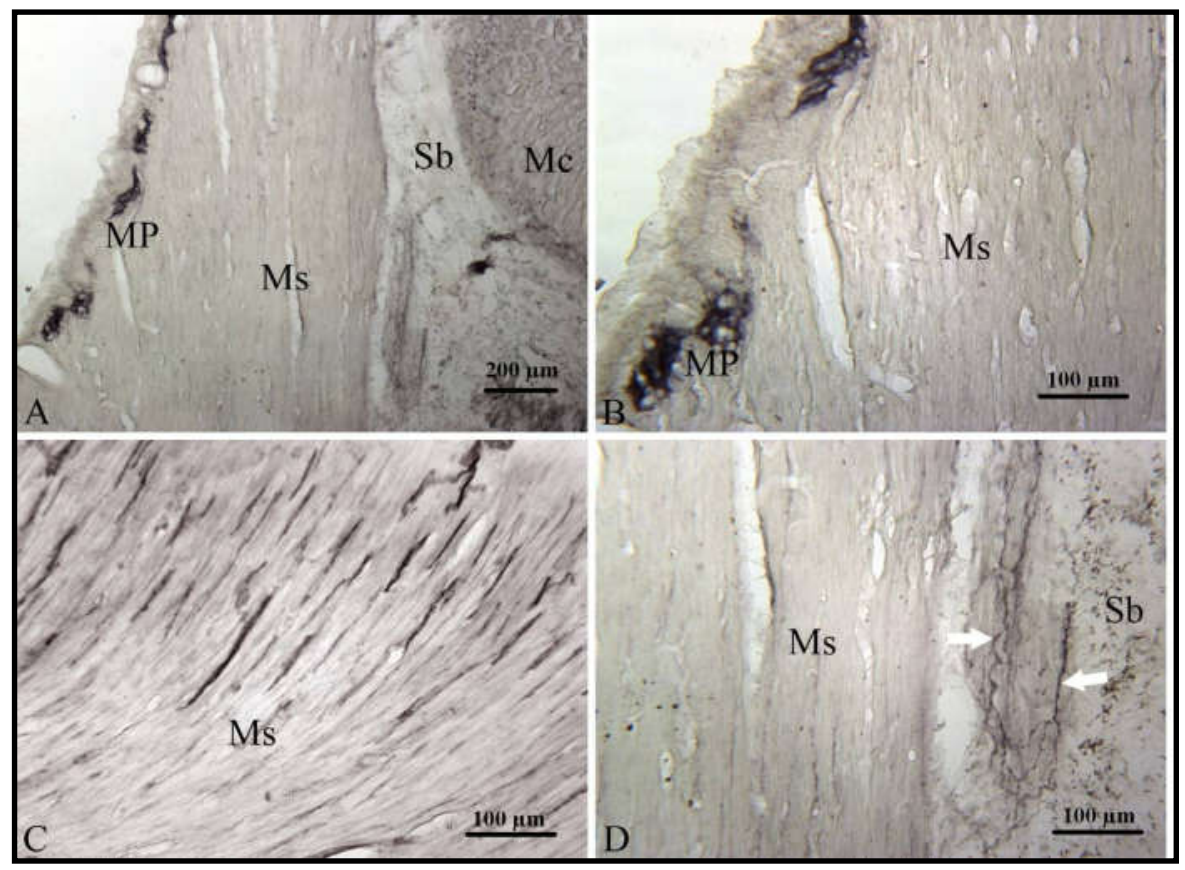

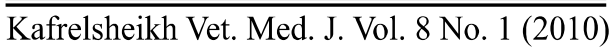


Fig. (3):

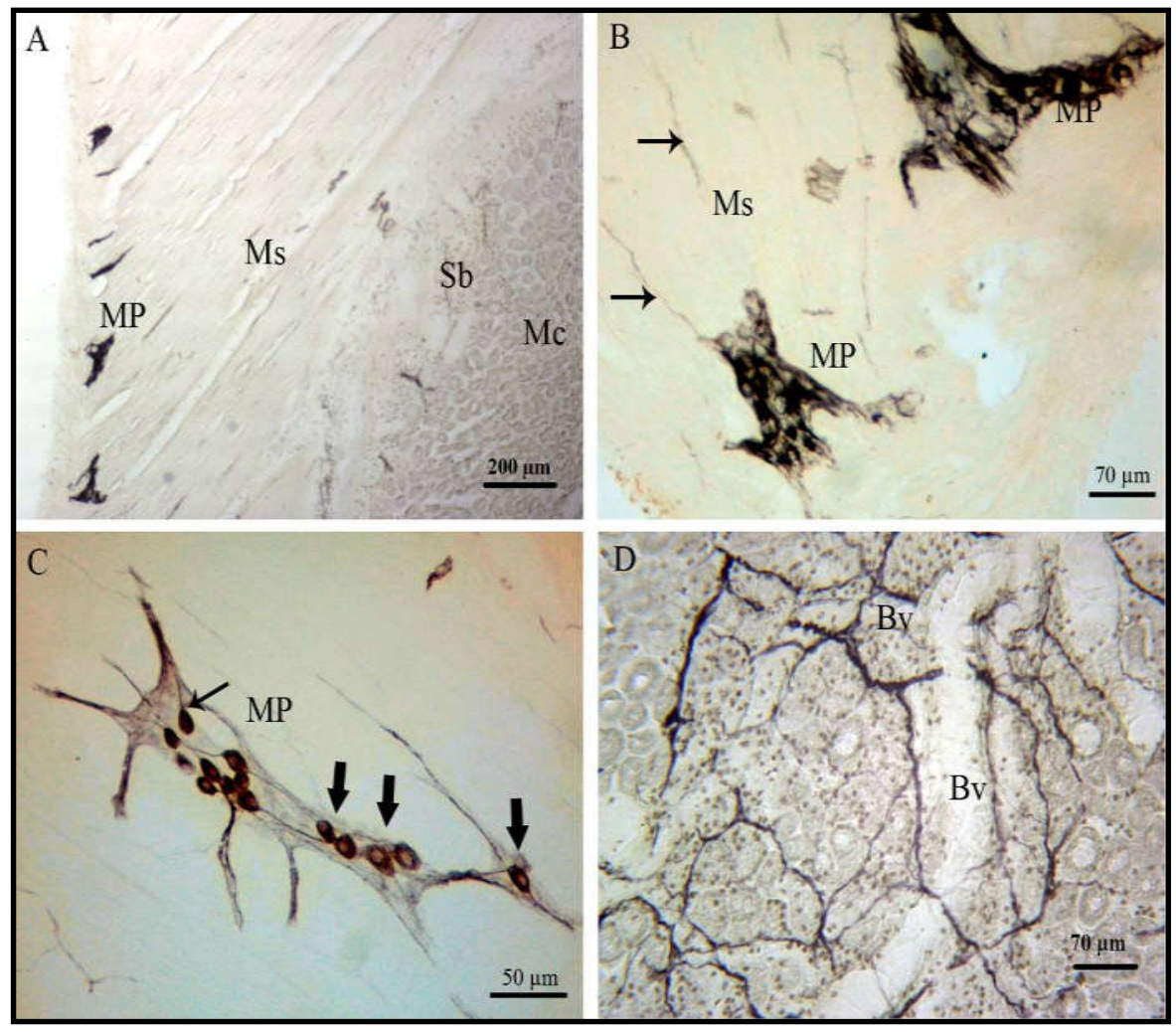

Fig. (4):

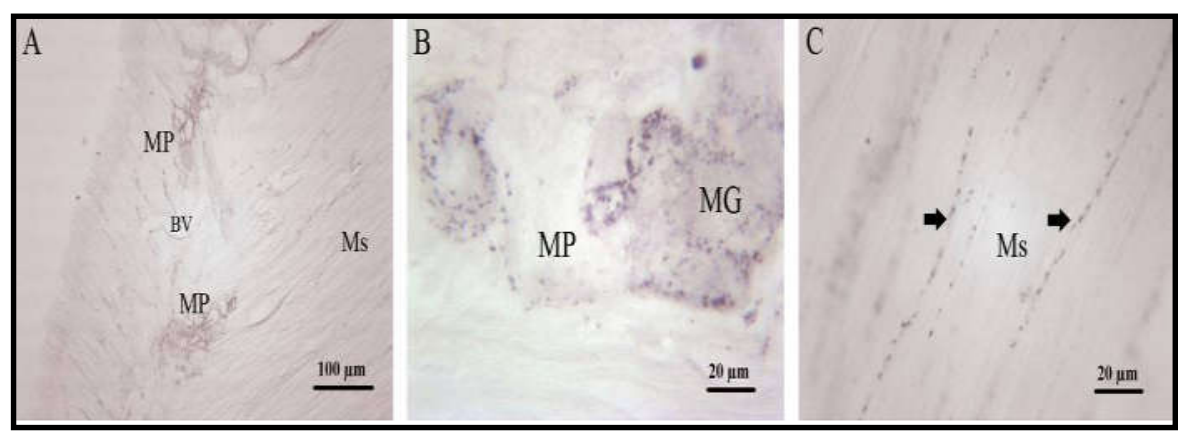

$\overline{\overline{\text { Kafrelsheikh Vet. Med. J. Vol. } 8 \text { No. } 1 \text { (2010) }}}$ 
Fig. (5):

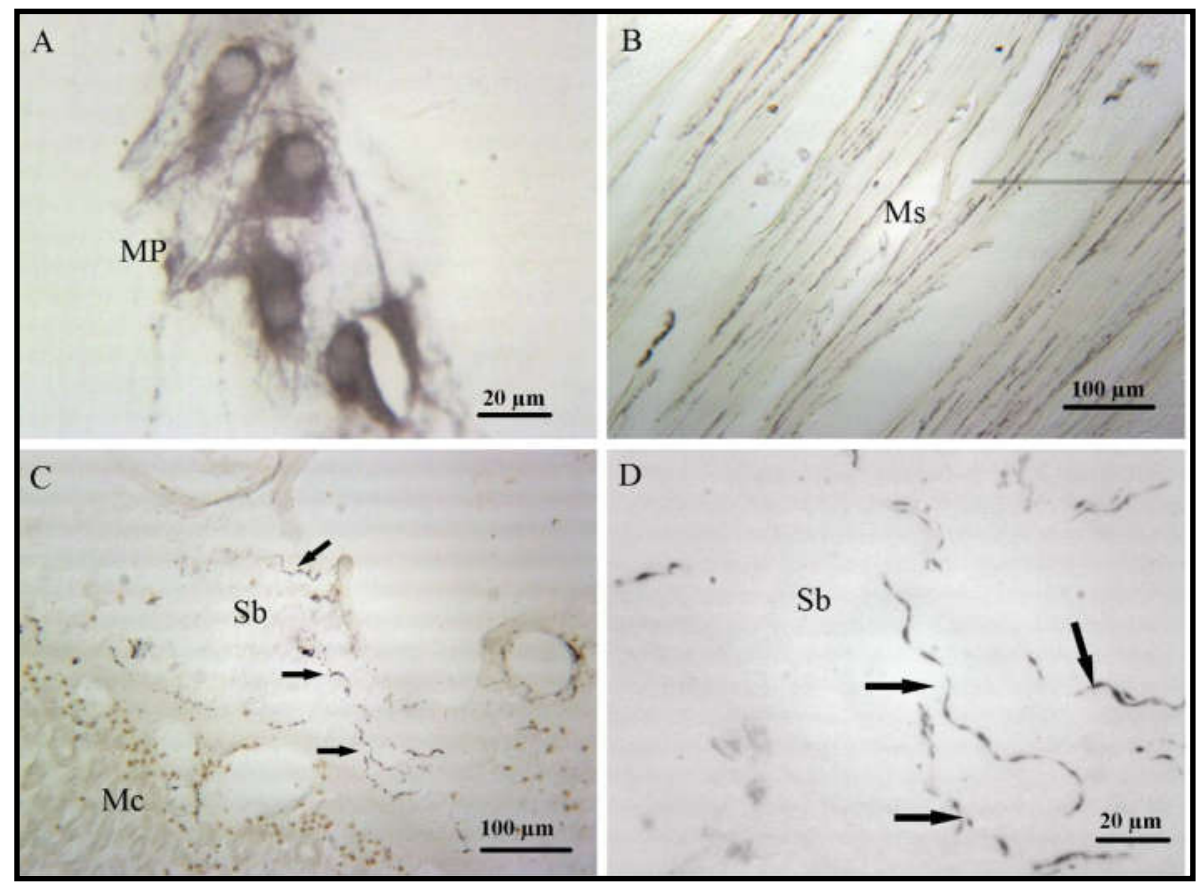

REFERENCES

- Adami M, Frati P, Bertini S, Kulkarni-Narla A, Brown DR, de Caro G, Coruzzi G, Soldani G. Gastric antisecretory role and immunohistochemical localization of cannabinoid receptors in the rat stomach. Br J Pharmacol 2002; 135:1598-606.

- Aimi Y,Kimura H,Kinoshita T, Minami Y, Fujimura M, Vincent SR. Histochemical localization of nitric oxide synthase in rat enteric nervous system. Neurosci 1993; 53:553-60.

- Arnhold S, When M, Labbé D, Andressen C, Addicks K. Transient expression of NOS-II during development of the murine enteric nervous system. J Mol Histol 2004; 35:741-48.

$\overline{\text { Kafrelsheikh Vet. Med. J. Vol. } 8 \text { No. } 1 \text { (2010) }}$ 
- Arvidsson U, Riedl M, Elde R, Meister B. Vesicular acetylcholine transported (VAChT) protein: a novel and unique marker for cholinergic neurons in the central and peripheral nervous systems. J Comp Neurol 1997; 378:454-67.

- Berthoud HR. Anatomical demonstration of vagal input to nicotinamide acetamide dinucleotide phosphate diaphorase-positive (nitrergic) neurons in rat fundic stomach. J Comp Neurol 1995; 358:428-39.

- Brehmer A, Schrödl F, Neuhuber W, Tooyama I, Kimura H. Coexpression pattern of neuronal nitric oxide synthase and two variants of choline acetyltransferase in myenteric neurons of porcine ileum. $\mathrm{J}$ Chem Neuroanat 2004; 27:33-41.

- Brookes SJ. Neuronal nitric oxide in the gut. J Gastroenterol Hepatol 1993; 8:590-603.

- Browning KN, Cunningham SM, Duncan L, Timmermans J, Lees $\boldsymbol{G M}$. Regional differences in the sympathetic innervation of the guinea pig large intestine by neuropeptide $\mathrm{Y}$ - and tyrosine hydroxylaseimmunoreactive nerves of divergent extrinsic origin. J Comp Neurol 1999; 410:515-30.

- Chiocchetti R, Poole DP, Kimura H, Aimi Y, Robbins HL, Castelucci P, Furness JB. Evidence that two forms of choline acetyltransferase are differentially expressed in subclasses of enteric neurons. Cell Tissue Res 2003; 311:11-22.

- Dawirs RR, Teuchert-Noodt G, Kampen WU. Demonstration of dopamine-immunoreactive cells in the gastrointestinal tract of gerbils (Meriones unguiculatus). J Histochem Cytochem 1992; 40:1197-201. 
- Dockray G. Physiology of enteric neuropeptides. In: Johnson LR (ed) Physiology of the gastrointestinal tract, $3^{\text {rd }}$ edn. Raven, New York, (1994) pp 169-209.

- Dun SL, Brailoiu GC, Brailoiu E, Yang J, Chang JK, Dun NJ. Distribution and biological activity of obestatin in the rat. J Endocr 2006; 191:481-9.

- Ferreira M, Ebert SN, Perry DC, Yasuda RP, Baker CM, DávilaGarcia MI, Kellar KJ, Gillis RA. Evidence of a functional alpha 7neuronal nicotinic receptor subtype located on motoneurons of the dorsal motor nucleus of the vagus. J Pharmacol Exp Ther 2001; 296:260-9.

- Finkel Y, Eklöf AC, Granquist L, Soares-da-Silva P, Bertorello AM. Endogenous dopamine modulates jejunal sodium absorption during high-salt diet in young but not in adult rats. Gastroenterology 1994; 107:675-9.

- Flemström G, Säfsten B, Jedstedt G. Stimulation of mucosal alkaline secretion in rat duodenum by dopamine and dopaminergic compounds. Gastroenterology 1993; 104:825-33.

- Furness JB, Costa M. Neurons with 5-hydroxytryptamine-like immunoreactivity in the enteric nervous system: their projections in the guinea-pig small intestine. Neuroscience 1982; 7:341-9.

- Furness JB, Koopmans HS, Robbins HL, Lin HC. Identification of intestinofugal neurons projecting to the coeliac and superior mesenteric ganglia in the rat. Auton Neurosci 2000; 83:81-5. 
- Furness JB, Lloyd KC, Sternini C, Walsh JH. Evidence that myenteric neurons of the gastric corpus project to both the mucosa and the external muscle: myectomy operations on the canine stomach. Cell Tissue Res 1991; 266:475-81.

- Gershon M, Kirchgessner A, Wade P. Functional anatomy of the enteric nervous system. In: Physiology of the Gastrointestinal Tract, edited by Johnson LR. New York: Raven 199 ₹; 381-422.

- Glavin GB, Hall AM. Central and peripheral dopamine D1/DA1 receptor modulation of gastric secretion and experimental gastric mucosal injury. Gen Pharmacol 1995; 26:1277-9.

- Guo JJ, Browning KN, Rogers RC, Travagli RA. Catecholaminergic neurons in rat dorsal motor nucleus of vagus project selectively to gastric corpus. Am J Physiol Gastrointest Liver Physiol 2001; 280:G361-7.

- Harrington AM, Hutson JM, Southwell BR. Immunohistochemical localization of substance P NK1 receptor in guinea pig distal colon. Neurogastroenterol Motil 2005;17:727-7.

- Harrington AM, Hutson JM, Southwell BR. High affinity choline transporter immunoreactivity in rat ileum myenteric nerves. Cell Tissue Res 2007; 327:421-31.

- Haskel Y, Hanani M. Inhibition of gastrointestinal motility by MPTP via adrenergic and dopaminergic mechanisms. Dig Dis Sci 1994; 39:2364-7. 
- Holst MC, Kelly JB, Powley TL. Vagal preganglionic projections to the enteric nervous system characterized with Phaseolus vulgarisleucoagglutinin. J Comp Neurol 1997; 381:81-100.

- Hoover DB, Ganote CE, Ferguson SM, Blakely RD, Parsons RL. Localization of cholinergic innervation in guinea pig heart by immunohistochemistry for high-affinity choline transporter. Cardiovasc Res 2004; 62:112-21.

- Iino S. Muscular innervation of the proximal duodenum of the guinea pig. Arch Histol Cytol 2000; 63:327-43.

- Jarvinen MK, Wollmann WJ, Powrozek TA, Schultz JA, Powley TL. Nitric oxide synthase-containing neurons in the myenteric plexus of the rat gastrointestinal tract: distribution and regional density. Anat Embryol (Berl) 1999; 199:99-112.

- Johnson RJ, Schemann M, Santer RM, Cowen T. The effects of age on the overall population and on sub-populations of myenteric neurons in the rat small intestine. J Anat 1998; 192: 479-88.

- Kanayama H, Yasuhara O, Matsuo A, Tooyama I, Aimi Y, Bellier $\boldsymbol{J P}$, Nagy JI, Kimura $\boldsymbol{H}$. Expression of a splice variant of choline acetyltransferase in magnocellular neurons of the tuberomammillary nucleus of rat. Neuroscience 2003; 118:243-51.

- Keast JR, Furness JB, Costa M. Distribution of certain peptidecontaining nerve fibres and endocrine cells in the gastrointestinal mucosa in five mammalian species.J Comp Neurol 1985;236:403-22.

- Kurosawa S, Hasler WL, Torres G, Wiley JW, Owyang C. Characterization of receptors mediating the effects of dopamine on gastric smooth muscle. Gastroenterology 1991; 100:1224-31. 
- Lee HS, Nam YS. Immunohistochemical localization of calcium binding proteins and some neurotransmitters in myenteric plexus of goat stomach. J Vet Sci 2006; 7:315-19.

- Li ZS, Fox-Threlkeld JE, Furness JB. Innervation of intestinal arteries by axons with immunoreactivity for the vesicular acetylcholine transporter (VAChT). J Anat 1998; 192:107-17.

- Li ZS, Furness JB. Immunohistochemical localization of cholinergic markers in putative intrinsic primary afferent neurons of the guineapig small intestine. Cell Tissue Res 1998; 294:35-43.

- Li ZS, Pham TD, Tamir H, Chen JJ, Gershon MD. Enteric dopaminergic neurons: definition, developmental lineage, and effects of extrinsic denervation. J Neurosci 2004; 24:1330-39.

- Mann PT, Furness JB, Southwell BR. Choline acetyltransferase immunoreactivity of putative intrinsic primary afferent neurons in the rat ileum. Cell Tissue Res 1999; 297:241-8.

- Mazzuoli G, Lucherini MC, Russo D, Clavenzani P, Chiocchetti R. Intrinsic neuronal control of the pyloric sphincter of the lamb. J Chem Neuroanat 2008; 36:98-106.

- Mezey E, Eisenhofer G, Harta G, Hannson S, Gould L, Hunyady B, Hoffman BJ. A novel nonneuronal catecholaminergic system: exocrine pancreas synthesizes and releases dopamine. Proc Natl Acad Sci USA 1996; 93:10377-82.

- Mezey E, Palkovits M. Localization of targets for anti-ulcer drugs in cells of the immune system. Science 1992; 258:1662-5. 
- Michel K, Reiche D, Schemann M. Projections and neurochemical coding of motor neurones to the circular and longitudinal muscle of the guinea pig gastric corpus. Pflugers Arch 2000; 440:393-408.

- Miller SM, Reed D, Sarr MG, Farrugia G, Szurszewski JH. Haem oxygenase in enteric nervous system of human stomach and jejunum and co-localization with nitric oxide synthase. Neurogastroenterol Motil 2001;13:121-31.

- Nakajima K, Tooyama I, Yasuhara O, Aimi Y, Kimura H. Immunohistochemical demonstration of choline acetyltransferase of a peripheral type (pChAT) in the enteric nervous system of rats. J Chem Neuroanat 2000; 18:31-40.

- Nakamura K, Takahashi T, Taniuchi M, Hsu CX, Owyang C. Nicotinic receptor mediates nitric oxide synthase expression in the rat gastric myenteric plexus. J Clin Invest 1998; 101:1479-89.

- Neunlist M, Michel K, Aubé A, Galmiche JP, Schemann M. Projections of excitatory and inhibitory motor neurons to the circular and longitudinal muscle of the guinea pig colon. Cell Tissue Res $2001 ; 305: 325-30$.

- Pfannkuche H, Reiche D, Firzlaff U, Sann H, Schemann M. Enkephalin-immunoreactive subpopulations in the myenteric plexus of the guinea-pig fundus project primarily to the muscle and not to the mucosa. Cell Tissue Res 1998b; 294:45-55.

- Pfannkuche H, Reiche D, Sann H, Schemann M. Different subpopulations of cholinergic and nitrergic myenteric neurones project to mucosa and circular muscle of the guinea-pig gastric fundus. Cell Tissue Res 1998a; 292:463-75. 
- Pimont S, Bruley des Varannes S, Le Neel JC, Aubert P, Galmiche $\boldsymbol{J P}$, Neunlist M. Neurochemical coding of myenteric neurones in the human gastric fundus. Neurogastroenterol Motil 2003; 15: 655-62.

- Rauch U, Klotz M, Maas-Omlor S, Wink E, Hänsgen A, Hagl C, Holland-Cunz S, Schäfer KH. Expression of intermediate filament proteins and neuronal markers in the human fetal gut. J Histochem Cytochem 2006; 54:39-46.

- Reiche D, Huber K, Hoppe S, Schemann M. Neurochemically distinct myenteric neurone populations containing calbindin have specific distribution patterns around the circumference of the gastric corpus. Cell Tissue Res 2001; 303:319-28.

- Reiche D, Schemann M. Mucosa of the guinea pig gastric corpus is innervated by myenteric neurones with specific neurochemical coding and projection preferences. J Comp Neurol 1999; 410:489-502.

- Ruggiero DA, Chau L, Anwar M, Mtui EP, Golanov EV. Effect of cervical vagotomy on catecholaminergic neurons in the cranial division of the parasympathetic nervous system. Brain Res 1993; 617:17-27.

- Sang Q, Young HM. Chemical coding of neurons in the myenteric plexus and external muscle of the small and large intestine of the mouse. Cell Tissue Res 1996; 284:39-53.

- Sarna SK. Gastrointestinal longitudinal muscle contractions. Am J Physiol 1993; G265:156-64. 
- Sarna SK. Enteric descending and afferent neural signaling stimulated by giant migrating contractions: essential contributing factors to visceral pain. Am J Physiol Gastrointest Liver Physiol 2007; 292:G572-81.

- Schemann M, Reiche D, Michel K. Enteric pathways in the stomach. Anat Rec 2001; 262:47-57.

- Schemann M, Schaaf C. Differential projection of cholinergic and nitroxidergic neurons in the myenteric plexus of guinea pig stomach. Am J Physiol 1995; 269:G186-95.

- Schemann M, Schaaf C, Mäder M. Neurochemical coding of enteric neurons in the guinea pig stomach. J Comp Neurol 1995; 353:161-78.

- Schicho R, Holzer P, Lippe IT. Gastric enteric neurones that respond to luminal injury. Neurogastroenterol Motil 2004; 16 Suppl 1:129-32.

- Schicho R,Schemann M,Holzer P, Lippe IT. Mucosal acid challenge activates nitrergic neurons in myenteric plexus of rat stomach. Am J Physiol Gastrointest Liver Physiol 2001; 281:G1316-21.

- Taylor GS, Bywater RA. Novel autonomic neurotransmitters and intestinal function. Pharmacol Ther 1989; 40:401-38.

- Toole L, Belai A, Burnstock G. A neurochemical characterisation of the golden hamster myenteric plexus.[Cell Tissue Res 1998; 291:385-94.

- Tooyama I, Kimura H. A protein encoded by an alternative splice variant of choline acetyltransferase mRNA is localized preferentially in peripheral nerve cells and fibers.J Chem Neuroanat 2000;7:217-26. 
- Vanden Berghe P, Coulie B, Tack J, Mawe GM, Schemann M, Janssens $\boldsymbol{J}$. Neurochemical coding of myenteric neurons in the guinea-pig antrum. Cell Tissue Res 1999; 297:81-90.

- Wang GD, Wang XY, Hu HZ, Fang XC, Liu S, Gao N, Xia Y, Wood JD. Angiotensin receptors and actions in guinea pig enteric nervous system. Am J Physiol Gastrointest Liver Physiol 2005;289:G614-26.

- Weihe E, Tao-Cheng JH, Schäfer MK, Erickson JD, Eiden LE. Visualization of the vesicular acetylcholine transporter in cholinergic nerve terminals and its targeting to a specific population of small synaptic vesicles. Proc Natl Acad Sci USA 1996; 93:3547-52.

- Welsh NJ, Shankley NP, Black JW. Comparative analysis of the vagal stimulation of gastric acid secretion in rodent isolated stomach preparations. Br J Pharmacol 1994; 112:93-6.

- Xu L, Depoortere I, Tomasetto C, Zandecki M, Tang M, Timmermans JP, Peeters TL. Evidence for the presence of motilin, ghrelin, and the motilin and ghrelin receptor in neurons of the myenteric plexus. Regul Pept 2005; 124:119-25.

- Yasuhara O, Matsuo A, Bellier JP, Aimi Y. Demonstration of choline acetyltransferase of a peripheral type in the rat heart. $J$ Histochem Cytochem 2007; 55:287-99.

- Yasuhara O, Tooyama I, Aimi Y, Bellier JP, Hisano T, Matsuo A, Park M, Kimura H. Demonstration of cholinergic ganglion cells in rat retina: expression of an alternative splice variant of choline acetyltransferase. J Neurosci 2003; 23:2872-81. 
- Young HM, Jones BR, McKeown SJ. The projections of early enteric neurons are influenced by the direction of neural crest cell migration. $J$ Neurosci 2002; 22:6005-18.

- Yuan PQ, Kimura H, Million M, Bellier JP, Wang L, Ohning GV, Taché $\boldsymbol{Y}$. Central vagal stimulation activates enteric cholinergic neurons in the stomach and VIP neurons in the duodenum in conscious rats. Peptides 2005; 26:653-64.

- Yuan P, Taché Y, Miampamba M, Yang H. Acute cold exposure induces vagally mediated Fos expression in gastric myenteric neurons in conscious rats. Am J Physiol Gastrointest Liver Physiol 2001; 281:G560-8.

- Yuan PQ, Yang $\boldsymbol{H}$. Neuronal activation of brain vagal-regulatory pathways and upper gut enteric plexuses by insulin hypoglycemia. Am J Physiol Endocrinol Metab 2002; 283: E436-48.

- Zheng H, Berthoud HR. Functional vagal input to gastric myenteric plexus as assessed by vagal stimulation-induced Fos expression. Am J Physiol Gastrointest Liver Physiol 2000; 279:G73-81. 


\section{توزيع المناعة النسجوكيميائية لبعض الببتيلات المنظمة فى معدة الفئران

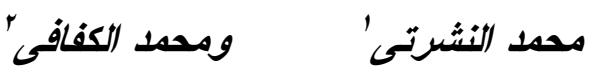

' قسم الأسجة والخلايا بكلية الطب البيطري بالبستان، جامعة الإسكندرية فرع دمنهور ץ قسم الأسجة والخلايا، كلية الطب البيطري، جامعة المنوفية فرع مدينة السادات

أجريت هذه الدراسة لإعادة تقييم التغذية العصبية لمعدة الفئران وذلك عن طريق تحديد المناعة النسجوكيميائية لبعض الواصمات الكولينية والتى شملت النوع الثائع من إنزيم الأسيتيل كولين الناقل و النوع الطرفى منه و الذى ينو اجد فى الأعصاب الكولينية الطرفية بصفة خاصة. علاوة على ذلك فقد تمت در اسة التو اجد المناعى للإنزيم الناقل لحويصلات الأسيتيل كولين و النوع العصبى من إنزيم تخليق أكسيد النتريك و إنزيم النتيروزين هيدروكسيليز . وتم ذلك بإستخدام مقاطع بر افين من معدة الفئران ومعاملتها بأجسام مضادة للأنزيمات المشار إليها. وقد أظهرت النتائج غياب شبه تام للضفيرة العصبية باطبقة تحت المخاطية فى جدار المعدة باستثاء بعض الخلايا المتفرقة. معظم الخلايا العصبية التى بالضفائر العصبية العضلومعوية أظهرت تفاعل إيجابى لكل من إنزيمى الأسيتيل كولين الناقل بنوعيه وإنزيم تخليق أكسيد النتريك بينما نواجد التفاعل المناعى للإنزيم الناقل لحويصلات الأسيتيل كولين و أنزيم التيروزين هيدروكسيليز فى أعصاب منوسعة ونهايات عصبية فى جدار المعدة. وتظهر هذه النتائج أنه فى جدار معدة الفئر هنانك تباين فى التقاعل مع البيتيدات المختبرة و الناقلات العصبية. فبينما غابت الضفيرة العصبية بالطبقة تحت المخاطية فقد تفاعلت الخلايا العصبية بضفيرة العضلومعوية مع كل من إنزيمى الأسيتيل الكولين الناقل الثائع والطرفى و إنزيم تخليق أكسيد النيتريك مفترضاً دليل شكلى على دور كل من الأعصاب الكولينية و النتروجينية $\overline{\text { Kafrelsheikh Vet. Med. J. Vol. } 8 \text { No. } 1 \text { (2010) }}$

$$
\text { و المحاكى الودى على وظائف المعدة الإفر ازية و الحركية. }
$$

